\title{
Study of 'Nonstress Test at Admission' and its Corelation with Maternal and Fetal Outcome
}

\author{
${ }^{1}$ Navneet Kaur, ${ }^{2}$ Promila Jindal
}

\section{ABSTRACT}

Introduction: Non stress test (NST) is the most widely used test for assessment of fetal health and reflects oxygenation of brain. NST is usually recommended after 30 to 32 weeks of the pregnancy. The false negative rate of NST (reactive NST in a fetus who actually is in distress) is $3.2 / 1000$ which is very low and thus NST is considered as a good predictor of fetal health.

Objectives: To evaluate the "NST at admission" in all the admitted women $>32$ weeks of gestation and to correlate it with type of labour and mode of delivery and maternal and neonatal outcome.

Materials and methods: This prospective study was conducted on all the pregnant women only at $>32$ weeks of gestation admitted to Dayanand Medical College and Hospital (DMCH), Ludhiana from 1/1/2011 to 31/12/2011. Non stress test was done in all women using TOCODYNAMOMETER for 20 minutes and was extended to next 20 minutes in case of inconclusive NST. Both the mother and neonate were followed up till discharge from hospital. The data was analysed statistically using $T$ test for quantitative variables and Chi square/Z test for qualitative variables.

Results: In 228 women, 233 NSTs (5 twins) were done and 24 NSTs needed 20 minutes extension to reach to conclusion.179 $(76.82 \%)$ NST were reactive while $54(23.18 \%)$ were non reactive. Women admitted with reactive NST had significantly higher vaginal delivery rates i.e. (39.78\% vs $11.54 \%$ ). Operative delivery in non reactive NST group was significantly higher than reactive NST group, i.e., (88.46\% vs $60.22 \%$ ). All 233 babies were born alive irrespective of the NST status and $47.21 \%$ (110) required NICU admission.

Conclusion: The 'NST at admission' is a simple method and is easy to perform for assessing fetal status antenatally and its reactivity assures good maternal and fetal outcome while non reactivity increases the chances of operative delivery and NICU admission.

Keywords: Cesarean, Diabetes, Perinatal outcome, Placenta previa, Pregnancy, Primigravida.

How to cite this article: Kaur N, Jindal P. Study of 'Nonstress Test at Admission' and its Corelation with Maternal and Fetal

\footnotetext{
${ }^{1}$ Senior Resident, ${ }^{2}$ Professor

${ }^{1}$ Department of Obstetrics and Gynecology, Government Medical College and Rajindra Hospital, Patiala, Punjab, India

${ }^{2}$ Department of Obstetrics and Gynecology, Punjab Institute of Medical Sciences, Jalandhar, Punjab, India

Corresponding Author: Navneet Kaur, Senior Resident, Department of Obstetrics and Gynecology, Government Medical College and Rajindra Hospital, Patiala, Punjab, India, e-mail: nav_neetu8@yahoo.in
}

Outcome. J South Asian Feder Obst Gynae 2018;10(3):161166.

\section{Source of support: Nil}

Conflict of interest: None

Date of received: 09/24/2016

Date of acceptance: 11/06/2016

Date of publication: December 2018

\section{INTRODUCTION}

In modern obstetrics antenatal fetal surveillance is becoming increasingly popular field for timely intervention for good fetal outcome. There are various modalities for antenatal fetal surveillance but NS) has withstood the test of time since its introduction. Non stress test is the most widely used test for assessment of fetal health and reflects oxygenation of brain. ${ }^{1}$ Fetal movements during testing are identified by maternal perception and are recorded. NST is based on the hypothesis that heart rate of fetus who is non acidotic, non impaired will temporarily accelerate in response to fetal movements. The fetal heart rate normally is increased or decreased by autonomic influences mediated by sympathetic or parasympathetic impulses from brain stem centres. Beat to Beat variability is under control of autonomic nervous system. Heart rate reactivity is believed to be a good indicator of normal fetal autonomic function. Consequently, pathological loss of acceleration may be seen in conjunction with significantly decreased beat to beat variability and fetal heart rate. 'NST at admission' at $\geq 32$ weeks of gestation ${ }^{2}$ is one such noninvasive technique by which 20 to 40 minutes of external fetal monitoring is used as a screening test to identify the time and mode of intervention according to its reactivity.

This prospective study was undertaken to evaluate and correlate 'NST at admission' with mode of delivery and fetal outcome (Birth weight, Apgar score, NICU admission).

\section{MATERIALS AND METHODS}

228 women admitted to labour room of DMCH Ludhiana for any reason at $\geq 32$ weeks of gestation irrespective of age, parity, maternal complications (BOH, DM, Fetal growth restriction (FGR), premature rupture of membranes (PROM), oligohydramnios), already in labor or for induction of labor were included in the study. NST 
was conducted on tocodynamometer for 20 minutes. The NST was interpreted as reactive when there were two or more accelerations of fetal heart rate that peak at 15 beats / minutes or more above baseline lasting for 15 seconds or more within $20 \mathrm{~min}$ and was labeled non-reactive if either Beat to beat variability $<5$ beats/minutes and/or no fetal movements and/or baseline fetal heart rate $<120$ or $>160$ beats / minutes and / or $<2$ accelerations or of $<15$ beats/minutes and/or presence of early, late and variable decelerations. If it did not fulfill either of above criteria, it was extended to 40 minutes to reach to conclusion. All women were followed up for mode of delivery, maternal and fetal outcome. APGAR score, birth weight, admission to nursery intensive care unit (NICU), duration of stay in nursery etc were noted for neonate. Both the mother and neonate were followed up till the time of discharge from hospital.

\section{Statistical analysis}

The data was analyzed statistically using $\mathrm{T}$ test for quantitative variables, Chi square/Z test for qualitative variables.

\section{OBSERVATIONS}

The study was conducted on 228 women and 233 NSTs were done (5 twin pregnancies) of which extended NSTs were done in 24 women. Of the total 233 NSTs, 179 $(76.2 \%)$ were reactive and $54(23.18 \%)$ were non reactive. There were 190 (83.33\%) booked cases and 38 (16.67\%) unbooked cases. In the booked cases, 194 NSTs were done (4 twin pregnancies) of which $154(79.38 \%$ ) were reactive and $40(20.62 \%)$ were non reactive; the difference being statistically significant $(\mathrm{p}=0.0450)$. In the unbooked cases, 39 NSTs were done (one twin pregnancy) of which $25(64.1 \%)$ were reactive and $14(35.9 \%)$ were non reactive (Fig. 1). Women admitted with reactive NST had significantly higher vaginal delivery rates, i.e., (39.78\% vs $11.54 \%$ ). Operative delivery in non reactive NST group was significantly higher than reactive NST group i.e. (88.46\% vs $60.22 \%$ ) (Table 1$)$.

A total of $166(72.80 \%)$ were high risk having pregnancy induced hypertension 65 (28.50\%), oligohydramnios with fetal growth restriction 55 (24.12\%), for induction of labor 37 (16.22\%) while 62 (27.19\%) were already in labor had no associated maternal disease (Table 2). There was statistically significant rate of caesarean section in women with $\mathrm{APH}$ both in reactive and non-reactive group. Similar trend was observed in women with oligohydramnios with FGR and PIH. While in low risk group the vaginal delivery rate was statistically more significant (67.85\% vs $30.35 \%)$ than caesarean section in reactive NST group and caesarean section rate was statistically more significant (71.42\% vs $28.57 \%$ ) than vaginal delivery in non reactive NST group. The difference in vaginal and caesarean section rate $\mathrm{w}$ as statistically significant in both the groups. $(\mathrm{p}=0.0481)$

Due to financial constraints $91 / 228$ women had Doppler velocimetry. All 19 women with non-reactive NST and abnormal Doppler had caesarean section while 20/21 women with reactive NST and abnormal Doppler had caesarean section but difference is not statistically significant ( $\mathrm{p}=0.1712$ ) (Table 3 ). Most common type of nonreactivity observed in women with non reactive NST, was no acceleration. Two women with early decelera-

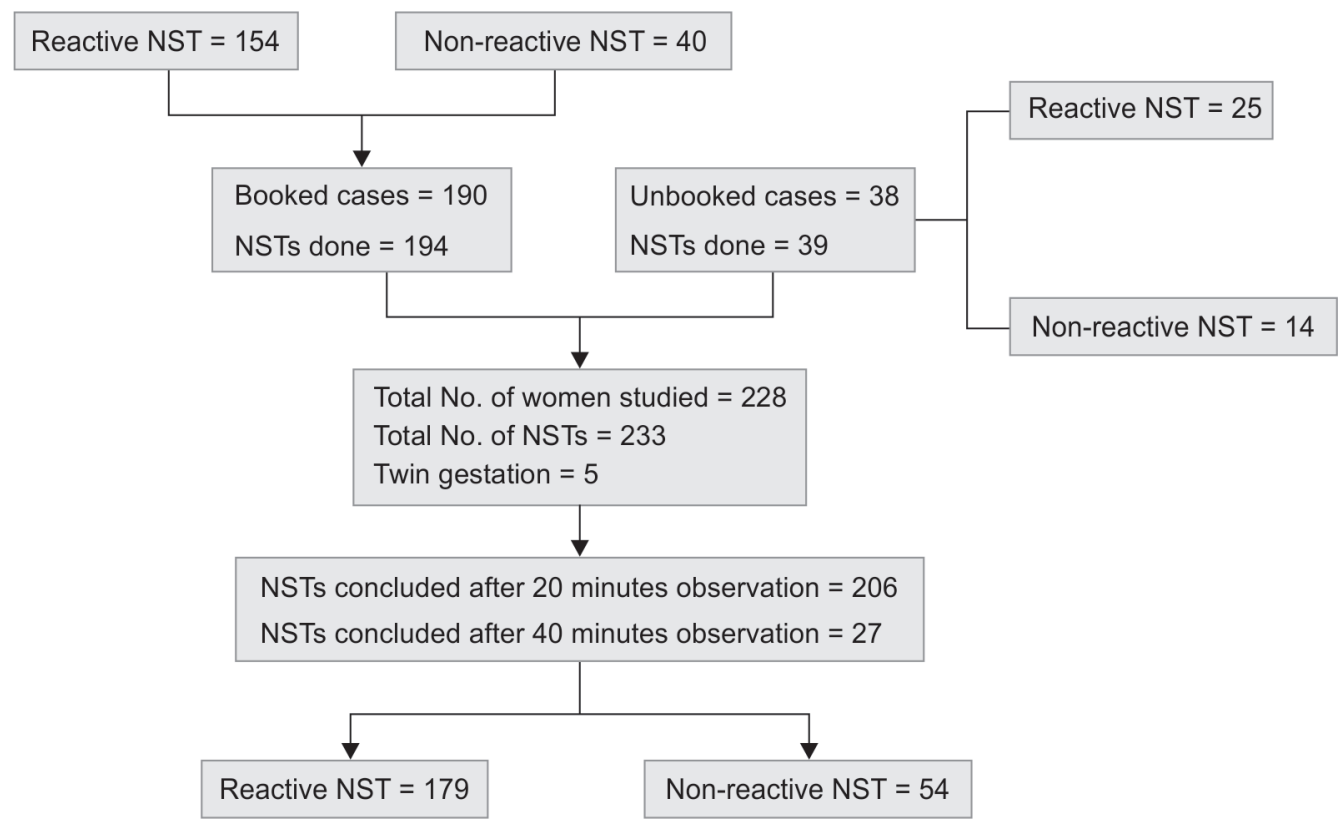

Fig. 1: Schematic representation of study 


\begin{tabular}{|c|c|c|c|c|c|c|c|}
\hline \multirow[b]{2}{*}{ Mode of delivery } & \multicolumn{2}{|c|}{$\begin{array}{l}\text { Total number of } \\
\text { women studied }\end{array}$} & \multicolumn{2}{|c|}{$\begin{array}{l}\text { No. of women with reac- } \\
\text { tive NST }(n=176)\end{array}$} & \multicolumn{2}{|c|}{$\begin{array}{l}\text { No. of women with non- } \\
\text { reactive NST }(n=52)\end{array}$} & \multirow[b]{2}{*}{$p$ value } \\
\hline & No. & $\%$ & No. & $\%$ & No. & $\%$ & \\
\hline Total caesarean section & 152 & 66.67 & 106 & 60.22 & 46 & 88.46 & $0.00681 \bullet$ \\
\hline \multirow[t]{2}{*}{ Emergency C-Section } & 89 & 58.55 & 54 & 30.68 & 35 & 67.31 & $0.00542^{\circ}$ \\
\hline & & & & $(50.94)$ & & (76.09) & \\
\hline \multirow[t]{2}{*}{ Elective C-Section } & 63 & 41.45 & 52 & 29.55 & 11 & 21.15 & 0.13983 \\
\hline & & & & $(49.06)$ & & (23.91) & \\
\hline Vaginal delivery & 76 & 33.33 & 70 & 39.78 & 6 & 11.54 & $0.00737^{\circ}$ \\
\hline Instrumental delivery & 10 & 4.39 & 9 & 5.11 & 1 & 1.92 & 0.16837 \\
\hline Total & 228 & 100 & 176 & 77.19 & 52 & 22.81 & \\
\hline
\end{tabular}

-Statistically significant

tion and $12.50 \%$ women with no acceleration delivered vaginally. Nearly $81.48 \%$ of the babies born to mothers with non reactive NST at admission were discharged in satisfactory condition.

All 233 babies born to 228 women were alive irrespective of their mother's NST status and $52.79 \%$ (123) babies were immediately shifted to mother and $47.21 \%$ (110) required NICU admission (Table 4). $75.92 \%$ babies born to mothers with non-reactive NST had NICU admission as compared to $38.55 \%$ babies with reactive NST $(p=0.0053)$. Four babies expired in the study and they were born to mothers admitted with non-reactive NST at admission (Table 4). Mean Apgar score of reactive NST group was significantly higher than non reactive NST group at 1 minute $(7.66 \pm 1.03$ vs $6.87 \pm 1.75)$ and at 5 minutes $(8.98 \pm 0.97$ vs $8.48 \pm 1.23)$ respectively (Table 4). Mean birth weight of babies was significantly higher in reactive NST group than non-reactive NST group in 32 to 37 weeks gestation $(1.76 \pm 0.33$ vs $1.39 \pm 0.34 \mathrm{~kg}$ in $32-34$ weeks and $2.34 \pm 0.61 \mathrm{vs} 1.83 \pm 0.69 \mathrm{~kg}$ in $34-37 \mathrm{wks}$ (Table 5) but once gestation reached term, reactivity of NST lost its correlation with the birth weight. On correlating

Table 2: Correlation of the maternal disease with the mode of delivery with 'NST reactivity at admission'

\begin{tabular}{|c|c|c|c|c|c|c|c|c|c|c|c|c|}
\hline \multirow{3}{*}{ Indication } & \multirow[b]{2}{*}{$\begin{array}{l}\text { Total No. } \\
\text { of women } \\
\text { studied } \\
(n=228)\end{array}$} & \multicolumn{5}{|c|}{ Reactive NST } & \multicolumn{5}{|c|}{ Non-reactive NST } & \multirow[b]{2}{*}{$\begin{array}{l}p \text {-value } \\
\text { A/C }\end{array}$} \\
\hline & & $\begin{array}{l}\text { Num- } \\
\text { ber of } \\
\text { women } \\
\text { No. }\end{array}$ & $\begin{array}{l}\text { No. } \\
\text { of } \\
\text { NST }\end{array}$ & $\begin{array}{l}\text { Vaginal } \\
\text { delivery } \\
\text { No. } \\
(\%)\end{array}$ & $\begin{array}{l}\text { Cae- } \\
\text { sarean } \\
\text { section } \\
\text { No. } \\
(\%)\end{array}$ & $P$ value & $\begin{array}{l}\text { No. of } \\
\text { women }\end{array}$ & $\begin{array}{l}\text { No. } \\
\text { of } \\
\text { NST }\end{array}$ & $\begin{array}{l}\text { Vaginal } \\
\text { Delivery } \\
\text { No.(\%) }\end{array}$ & $\begin{array}{l}\text { Caesare- } \\
\text { an section } \\
\text { No. (\%) }\end{array}$ & $P$ value & \\
\hline & No. (\%) & $(\%)$ & & $A$ & $B$ & $A / B$ & NO.(\%) & & C & $D$ & $C / D$ & $B / D$ \\
\hline $\begin{array}{l}\text { Antepartum haem- } \\
\text { orrhage }(\mathrm{APH})\end{array}$ & $\begin{array}{l}5 \\
(2.19)\end{array}$ & $\begin{array}{l}3 \\
(60)\end{array}$ & 3 & None & $\begin{array}{l}3 \\
(100)\end{array}$ & $.04001 •$ & $\begin{array}{l}2 \\
(40)\end{array}$ & 2 & None & $\begin{array}{l}2 \\
(100)\end{array}$ & 0.0825 & 0 \\
\hline $\begin{array}{l}\text { Pregnancy with } \\
\text { DM }\end{array}$ & $\begin{array}{l}12 \bullet \\
(5.26)\end{array}$ & $\begin{array}{l}9 \\
(75)\end{array}$ & 9 & $\begin{array}{l}1 \\
(11.11)\end{array}$ & $\begin{array}{l}8 \\
(88.89)\end{array}$ & $.00704 \bullet$ & $\begin{array}{l}3 \\
(25)\end{array}$ & 3 & None & $\begin{array}{l}3 \\
(100)\end{array}$ & 0.0673 & $0.0091 \bullet$ \\
\hline $\begin{array}{l}\text { Oligohydramnios } \\
\text { with FGR }\end{array}$ & $\begin{array}{l}55 \bullet \\
(24.12)\end{array}$ & $\begin{array}{l}29 \\
(51.79)\end{array}$ & 29 & $\begin{array}{l}4 \\
(13.79)\end{array}$ & $\begin{array}{l}25 \\
(86.20)\end{array}$ & $.00468 \bullet$ & $\begin{array}{l}26 \\
(48.21)\end{array}$ & 27 & $\begin{array}{l}1 \\
(3.84)\end{array}$ & $\begin{array}{l}26 \\
(96.15)\end{array}$ & $00037 \bullet$ & 0.1247 \\
\hline $\begin{array}{l}\text { Pregnancy induced } \\
\text { hypertension (PIH) }\end{array}$ & $\begin{array}{l}65 \\
(28.50)\end{array}$ & $\begin{array}{l}34 \\
(52.31)\end{array}$ & 34 & $\begin{array}{l}8 \\
(23.52)\end{array}$ & $\begin{array}{l}26 \\
(76.47)\end{array}$ & $.00591 \bullet$ & $\begin{array}{l}31 \\
(47.69)\end{array}$ & 31 & $\begin{array}{l}2 \\
(3.08)\end{array}$ & $\begin{array}{l}29 \\
(44.62)\end{array}$ & $0.0037 \bullet$ & 0.0866 \\
\hline $\begin{array}{l}\text { Premature rupture } \\
\text { of membranes }\end{array}$ & $\begin{array}{l}34 \bullet \\
(14.91)\end{array}$ & $\begin{array}{l}26 \nabla \\
(77.14)\end{array}$ & 27 & $\begin{array}{l}13 \\
(50.00)\end{array}$ & $\begin{array}{l}13 \\
(50.00)\end{array}$ & 0.0000 & $\begin{array}{l}8 \\
(22.90)\end{array}$ & 8 & $\begin{array}{l}2 \\
(25.00)\end{array}$ & $\begin{array}{l}6 \\
(75.00)\end{array}$ & $0.0490 \bullet$ & 0.1419 \\
\hline $\begin{array}{l}\text { Pregnancy with } \\
\text { hepatitis }\end{array}$ & $\begin{array}{l}6 \bullet \\
(2.63)\end{array}$ & $\begin{array}{l}2 \\
(33.33)\end{array}$ & 2 & None & $\begin{array}{l}2 \\
(100.00)\end{array}$ & .0825 & $\begin{array}{l}4 \\
(66.66)\end{array}$ & 4 & $\begin{array}{l}2 \\
(50.00)\end{array}$ & $\begin{array}{l}2 \\
(50.00)\end{array}$ & 0 & 0.1347 \\
\hline $\begin{array}{l}\text { Pregnancy with } \\
\text { hypothyroidism }\end{array}$ & $\begin{array}{l}18 \bullet \\
(7.89)\end{array}$ & $\begin{array}{l}13 \\
(72.22)\end{array}$ & 13 & $\begin{array}{l}5 \\
(38.46)\end{array}$ & $\begin{array}{l}8 \\
(61.54)\end{array}$ & .14022 & $\begin{array}{l}5 \\
(27.80)\end{array}$ & 5 & None & $\begin{array}{l}5 \\
(100.00)\end{array}$ & 0.0521 & 0.1011 \\
\hline $\begin{array}{l}\text { For induction of } \\
\text { labour }\end{array}$ & $\begin{array}{l}37 \bullet \\
(16.22)\end{array}$ & $\begin{array}{l}36 \\
(97.30)\end{array}$ & 36 & $\begin{array}{l}18 \\
(50.00)\end{array}$ & $\begin{array}{l}18 \\
(50.00)\end{array}$ & 0 & $\begin{array}{l}1 \\
(2.70)\end{array}$ & 1 & None & $\begin{array}{l}1 \\
(100.00)\end{array}$ & 0.4121 & 0.1672 \\
\hline Already in labour & $\begin{array}{l}62 \bullet \\
(27.19)\end{array}$ & $\begin{array}{l}55 \nabla \\
(88.70)\end{array}$ & 56 & $\begin{array}{l}38 \\
(69.09)\end{array}$ & $\begin{array}{l}17 \\
(30.90)\end{array}$ & $.0065 \bullet$ & $\begin{array}{l}7 \\
(11.29)\end{array}$ & 7 & $\begin{array}{l}2 \\
(28.57)\end{array}$ & $\begin{array}{l}5 \\
(71.42)\end{array}$ & 0.1029 & $0.0481 \bullet$ \\
\hline
\end{tabular}

$\boldsymbol{\nabla}$ includes twins $\bullet$ had multiple indication •statistically significant 
Table 3: Corelation of Doppler velocimetry with the NST at admission and the mode of delivery

\begin{tabular}{|c|c|c|c|c|c|c|c|c|c|c|c|c|}
\hline & \multirow{3}{*}{$\begin{array}{l}\text { Total } \\
\text { no. of } \\
\text { women } \\
\text { studied }\end{array}$} & \multicolumn{5}{|c|}{ Reactive NST } & \multicolumn{5}{|c|}{ Non-reactive NST } & \multirow[b]{2}{*}{$p$-value } \\
\hline & & $\begin{array}{l}\text { No. of } \\
\text { women } \\
\text { No. (\%) }\end{array}$ & $\begin{array}{l}\text { No. of } \\
\text { NST }\end{array}$ & $\begin{array}{l}\text { Vaginal } \\
\text { delivery } \\
\text { No. }\end{array}$ & $\begin{array}{l}\text { Caesarean } \\
\text { section } \\
\text { No. }\end{array}$ & & \multirow{2}{*}{$\begin{array}{l}\text { No. of } \\
\text { women } \\
\text { No. }\end{array}$} & $\begin{array}{l}\text { No. of } \\
\text { NST }\end{array}$ & $\begin{array}{l}\text { Vaginal } \\
\text { Delivery } \\
\text { No }\end{array}$ & $\begin{array}{l}\text { Cae- } \\
\text { sarean } \\
\text { section } \\
\text { No. }\end{array}$ & \multirow[b]{2}{*}{$p$-value } & \\
\hline & & & \multirow{2}{*}{ No. (\%) } & $(\%)$ & (\%) & $p$-value & & \multirow[t]{2}{*}{ No. (\%) } & (\%) & (\%) & & $A / C$ \\
\hline & No. (\%) & & & $A$ & $B$ & $A / B$ & $(\%)$ & & C & $D$ & $C / D$ & $B / D$ \\
\hline \multirow{2}{*}{$\begin{array}{l}\text { Normal } \\
\text { Doppler }\end{array}$} & 51 & 41 & \multirow[t]{2}{*}{41} & 12 & 29 & \multirow[t]{2}{*}{$0.0068 \bullet$} & 10 & \multirow[t]{2}{*}{$11 \nabla$} & 2 & 8 & \multirow[t]{2}{*}{0.0096} & \multirow[t]{2}{*}{0.2802} \\
\hline & $(56.04)$ & (80.39) & & $(29.26)$ & (70.73) & & (19.61) & & (20.00) & $(80.00)$ & & \\
\hline \multirow{2}{*}{$\begin{array}{l}\text { Abnormal } \\
\text { Doppler* }\end{array}$} & 40 & 21 & \multirow[t]{2}{*}{21} & 1 & 20 & \multirow[t]{2}{*}{$0.0044 \bullet$} & 19 & \multirow[t]{2}{*}{$20 \nabla$} & \multirow[t]{2}{*}{ None } & 19 & \multirow[t]{2}{*}{0.0041 • } & \multirow[t]{2}{*}{0.1712} \\
\hline & $(43.96)$ & $(52.50)$ & & $(4.76)$ & (95.23) & & $(47.50)$ & & & (100) & & \\
\hline \multirow[t]{2}{*}{ Total } & $91 / 228$ & $62 / 91$ & 62 & \multirow{2}{*}{$\begin{array}{l}13 \\
(20.96)\end{array}$} & \multirow{2}{*}{$\begin{array}{l}49 \\
(79.03)\end{array}$} & \multirow[t]{2}{*}{0.0039 • } & \multirow[t]{2}{*}{29} & \multirow[t]{2}{*}{$31 \nabla$} & \multirow{2}{*}{$\begin{array}{l}2 \\
(6.89)\end{array}$} & \multirow{2}{*}{$\begin{array}{l}27 \\
(93.10)\end{array}$} & \multirow[t]{2}{*}{$0.0039 •$} & \multirow[t]{2}{*}{0.0978} \\
\hline & (39.91) & (68.13) & $(68.13)$ & & & & & & & & & \\
\hline
\end{tabular}

*Doppler abnormal - SD ratio in

uterine artery and umbilical artery $>3$

middle cerebral artery $<3$

- Statistically significant

fetal outcome with type of decelerations, 2 babies born to mothers with early deceleration were healthy till the time of discharge but babies born to mothers with variable (one) and late decelerations 3 either expired or took LAMA during NICU stay.

\section{DISCUSSION}

The fetal heart rate variability is interplay of sympathetic and parasympathetic impulses from fetal brain stem. Usually 20 minutes observation is sufficient to conclude the results of NST. If observation is inconclusive, it can be extended to 40 minutes. After 32 weeks of gestation, a reactive NST generally is a reassurance of good fetal health. NST is labeled reactive if there are two or more accelerations of FHR of $\geq 15$ beats / minutes above baseline, lasting for $\geq 15$ seconds in $20 \mathrm{~min}^{2}$ In our study with this criteria after extending the observation for 40 minutes in 27 women, 54/233 NST were non reactive and 179/233 were declared reactive. Others have concluded NST only after 20 minutes observation like Das et al. ${ }^{3}$ observed $73.71 \%$ reactive NST and $26.28 \%$ non reactive NST. Glantz et al. $^{4}$ concluded NST reactive after 15 or 10 beats per acceleration and on correlating with fetal outcome after making adjustment for gestational age and birth weight found that variation in number of beats/acceleration is ineffective but non reactive NST definitely has adverse affect on perinatal outcome. Overall in our study vaginal delivery rate was significantly more (39.78\% vs $11.54 \%$ ) in reactive NST group whereas caesarean section was more ( $88.46 \%$ vs $60.22 \%$ ) in non reactive NST group. On studying individual maternal risk factor, this trend was not observed. There was an increase in the caesarean section rate in high risk women even with a reactive NST at admission. This may be because the time and mode of termination of pregnancy in high risk women depended on maternal disease, its progression, severity and fetal

Table 4: Corelation of 'NST at admission' with fetal outcome

\begin{tabular}{|c|c|c|c|c|c|c|}
\hline \multirow{2}{*}{ Fetal outcome } & \multirow{3}{*}{$\begin{array}{l}\text { Total no. of } \\
\text { babies }\end{array}$} & \multicolumn{2}{|c|}{ Reactive NST ( $n=179)$} & \multicolumn{2}{|c|}{ Non-reactive NST $(n=54)$} & \multirow{2}{*}{$\begin{array}{l}p \text {-value } \\
A / B\end{array}$} \\
\hline & & \multirow{2}{*}{$\begin{array}{l}\begin{array}{l}\text { No. of alive } \\
\text { births (\%) A }\end{array} \\
179\end{array}$} & \multirow{2}{*}{$\begin{array}{l}\% \\
100\end{array}$} & \multicolumn{2}{|c|}{ No. of alive births (\%) B \% } & \\
\hline Alive at birth & & & & 54 & 100 & \\
\hline \multirow{2}{*}{$\begin{array}{l}\text { Shifted to mother } \\
\text { NICU admission }\end{array}$} & $123(52.79)$ & 110 & 89.43 & 13 & 10.57 & $0.0004 \bullet$ \\
\hline & $110 / 233$ & $69 / 179$ & $69 / 110$ & $41 / 54$ & $41 / 110$ & $0.0068 \bullet$ \\
\hline & $(47.21)$ & $(38.55)$ & $(62.73)$ & $(75.92)$ & $(37.27)$ & $0.0053 \bullet$ \\
\hline •LAMA & $\begin{array}{l}9 / 110 \\
(8.18)\end{array}$ & 3 & 33.33 & 6 & 66.67 & 0.1166 \\
\hline •Expired during NICU stay & $\begin{array}{l}4 \\
(3.65)\end{array}$ & 0 & 0 & 4 & 100.0 & 0.0583 \\
\hline \multirow{2}{*}{$\begin{array}{l}\text { Mean APGAR } \\
\text { score } \pm \text { SD }\end{array}$} & & \multicolumn{2}{|l|}{$7.66 \pm 1.03$} & \multicolumn{2}{|l|}{$6.87 \pm 1.75$} & $0.00625 \bullet$ \\
\hline & & \multicolumn{2}{|l|}{$8.98 \pm 0.97$} & $8.48 \pm 1.23$ & & $0.00829 \bullet$ \\
\hline
\end{tabular}




\begin{tabular}{|c|c|c|c|c|c|c|c|c|}
\hline \multirow[b]{2}{*}{$\begin{array}{l}\text { Gestational } \\
\text { age (weeks) }\end{array}$} & \multirow{2}{*}{$\begin{array}{l}\text { Total } \\
\text { number of } \\
\text { babies } \\
(n=233)\end{array}$} & \multicolumn{2}{|c|}{ Reactive NST $(n=179)$} & \multicolumn{4}{|c|}{ Non-reactive $(n=54)$} & \multirow[b]{2}{*}{$\begin{array}{l}p \text {-value of } \\
\text { mean birth } \\
\text { weight }\end{array}$} \\
\hline & & $\begin{array}{l}\text { No. of 'NST } \\
\text { at admission' }\end{array}$ & $\begin{array}{l}\text { Mean birth } \\
\text { weight } \\
(\mathrm{kg}) \pm S D\end{array}$ & $\begin{array}{l}\text { Median } \\
\text { (range) }\end{array}$ & $\begin{array}{l}\text { No. of 'NST } \\
\text { at admission', }\end{array}$ & $\begin{array}{l}\text { Mean birth } \\
\text { weight } \\
(\mathrm{kg}) \pm S D\end{array}$ & $\begin{array}{l}\text { Median } \\
\text { (range) }\end{array}$ & \\
\hline \multirow[t]{2}{*}{$32-34$} & 39 & 18 & $1.76 \pm 0.33$ & 1.81 & 21 & $1.39 \pm 0.34$ & 1.39 & $0.0075 \bullet$ \\
\hline & & & & $(0.945-4.57)$ & & & $(0.77-3.71)$ & \\
\hline \multirow[t]{2}{*}{$34.1-37$} & 69 & 50 & $2.34 \pm 0.61$ & 2.30 & 19 & $1.83 \pm 0.69$ & 1.70 & $0.0086 \bullet$ \\
\hline & & & & $(0.945-4.57)$ & & & $(0.77-3.71)$ & \\
\hline \multirow[t]{2}{*}{$37.1-40$} & 110 & 98 & $2.97 \pm 0.44$ & 2.95 & 12 & $3.03 \pm 0.54$ & 3.20 & 0.3794 \\
\hline & & & & $(0.945-4.57)$ & & & $(0.77-3.71)$ & \\
\hline \multirow[t]{2}{*}{$>40$} & 15 & 13 & $3.44 \pm 0.51$ & 3.25 & 2 & 3.01 & - & - \\
\hline & & & & $(0.945-4.57)$ & & & & \\
\hline
\end{tabular}

-Statistically significant

affection and not only on reactivity of NST at admission. Roberts et al. ${ }^{5}$ on computerized analysis of fetal heart tracings concluded that absence of episodes of high variation or absence of accelerations is not an abnormal finding at 24-28 weeks of gestation and reactive NST means a good fetal status and assures vaginal delivery in the absence of other factors.

No doubt Doppler velocimetry is costly but when combined with NST, it becomes a more specific/reliable parameter of fetal health which is supported by Turan $S$ et al. ${ }^{6}$ study who found that computerized analysed NST with venous Doppler as best predictor of acid base status of growth restricted fetuses andeven recommended that computerized CTG combined with venous Doppler as a substitute of the traditional NST in the biophysical score. Radhika and Lavanya ${ }^{1}$ in their study of pre eclampsia with IUGR cases also observed that when both Doppler and NST was normal $55 \%$ had vaginal delivery and when only Doppler was abnormal 100\% women had caesarean section. With Doppler study remaining normal and NST non reactive, vaginal delivery rate decreased from $23.52 \%$ to $3.85 \%$ but when both NST and Doppler became abnormal $100 \%$ women had caesarean section.

Non reactive NST correlates well with lower APGAR score, low birth weight, increased NICU admissions and adverse fetal outcome. No doubt in our study all babies were born alive irrespective of their mother's NST status, $47.21 \%$ were NICU admissions and $75.92 \%$ NICU admission were from non reactive NST group and 4 babies expired during NICU stay belonged to non-reactive NST group, where as Das et al. ${ }^{7}$ had only $19.05 \%$ NICU admissions in lowered modified biophysical score, probably they studied modified biophysical profile in women with $>34$ weeks of gestation. $\mathrm{Xu} \mathrm{H}^{8}$ also had increasingly higher perinatal mortality with increasing severity of abnormal fetal heart rate tracings in muconium stained liquor women, $15.1 \%$ in normal tracing, $21.3 \%$ in moder- ately abnormal tracing and $33.8 \%$ in markedly abnormal tracing. Same is the observation by Sood ${ }^{9}$ who on studying vibroacoustic stimulated modified fetal biophysical profile in high risk women antenatally, reported higher $(1.8 \%)$ perinatal mortality in non reactive NST group.

In our study mean Apgar score of babies of reactive NST group was significantly higher at 1 minute $(7.66 \pm$ 1.03 vs $6.87 \pm 1.75)$ and at 5 minutes $(8.98 \pm 0.97$ vs $8.48 \pm$ 1.23). Das et al. ${ }^{7}$ also observed higher Apgar score $>7$ in reactive NST group than non reactive NST group $(67.77 \%$ vs $32.23 \%$ ). Miller et al. ${ }^{10}$ also concluded that babies with birth weight $<10$ percentile for gestational age were increased in the non reactive NST group and even in our study mean birth weight in reactive NST group was higher $(2.12 \pm 0.46)$ at 32-37 weeks gestation.

\section{ACKNOWLEDGMENT}

Authors are highly thankful to all their teachers and family who encouraged them in every aspect of my life. Authors are thankful to Dr Promila Jindal who helped them in collecting the material and writing this topic. This paper has been possible due to joint effort of my co-author as well. Authors really appreciate the work of juniors who helped them in this topic a lot. This study has been conducted retrospectively, so no harm has been inflicted upon the patients involved in the study. Thank you Dr Navneet.

\section{CONCLUSION}

To conclude, 'NST at admission' is quite a convenient method for assessing fetal status antenatally and its reactivity assures good maternal and fetal outcome. Although it is not the final and only test to rely upon because its non reactivity requires more investigations like complete biophysical profile and colour Doppler velocimetry but it definitely increases the chances of operative delivery and NICU admission hence adverse fetal outcome as seen in our study. 


\section{REFERENCES}

1. Radhika P and Lavanya R. Fetal Doppler versus NST as predictors of adverse perinatal outcome in severe preeclampsia and fetal growth restriction. J Obstet Gynecol India. 2006;56:134138.

2. Cunningham FG. Intrapartum Assessment Edited by Cunningham FG, Leveno KJ, Bloom SL, Hauth JC, Rouse DJ, Spong CY. Williams Obstetrics 23/ed. USA, McGraw Hill 2010; 410-414

3. Das V, Katiyar N, Malik G K. Role of Admission Test. J Obstet Gynecol India. 2001;51(1):48-50.

4. Glantz J C, Bertoia N. Preterm nonstress testing: 10-beat compared with 15-beat criteria. Am J Obstet Gynecol. 2011 July; 118(1): 87-93.

5. Roberts D, Kumar B, Tincello D G, Walkinshaw S A. Computerised antenatal fetal heart rate recordings between 24 and 28 weeks gestation. British J Obstet Gynecol. 2001 Aug;108(8):858-862.
6. Turan S, Turan O M, Berg C, Moyano D, Bhide A, Bower S, et al. Computerised fetal heart rate analysis, Doppler ultrasound and biophysical profile score in the prediction acid-base status of growth restricted fetuses. Ultrasound Obstet Gynecol 2007 Oct; 30(5):750-756

7. Das V, Agrawal D, Malik GK, Kumar P. Modified Biophysical Profile and Fetal Outcome. J Obstet Gynecol India. 2001; 51(5) 101-104.

8. Xu H, Mas-Calvet M, Wei S Q, Luo S, Fraser W D. Abnormal fetal heart rate tracing patterns in patients with thick meconium staining of the amniotic fluid: association with perinatal outcomes. Am J Obstet Gynecol. 2009 Mar; 200(3): 283-285.

9. Sood A K. Vibroacoustic stimulation and modified fetal biophysical profile in high risk pregnancy. J Obstet Gynecol of India. 2007 Jan 1;57(1):37-41.

10. Miller DA, Rabello YA, Richard HP. The modified biophysical profile: Antepartum testing in the 1990s. Am J Obstet Gynecol. 2006 Mar;174(3):812-817. 